\title{
Kajian Sedimentasi pada DAS Sail Pekanbaru dengan menggunakan SIG dan Metode Usle
}

\author{
Aisah Kurnia Utami ${ }^{1}$, Bambang Sujatmoko ${ }^{2}$, Manyuk Fauzi ${ }^{3}$ \\ 1,2,3 Program Studi Teknik Sipil, Fakultas Teknik, Universitas Riau \\ Kampus Bina Widya Jl. HR Soebrantas KM 12,5 Pekanbaru, Kode Pos 28293 Telp. (0761) 52324 \\ Email: Aisah.kurnia@student.unri.ac.id, b.sujatmoko@eng.unri.ac.id, manyuk.fauzi@unri.ac.id
}

\begin{abstract}
ABSTRAK
Perubahan tata guna lahan pada DAS Sail akan merubah aliran permukaan dan menyebabkan erosi dan sedimentasi. Metode USLE digunakan untuk mengestimasi erosi pada lahan dan SIG berguna untuk memprediksi besar parameter USLE. Hasil analisis menunjukkan erosi yang terjadi pada DAS Sail adalah kategori kelas rendah (15-60 ton/ha/tahun). Potensi erosi yang masuk ke sungai sebesar 25924.7115 ton/tahun. Hasil penelitian menunjukkn bahwa Pada sebagian sub DAS Sail terjadi sedimen lahan karena nilai erosi lebih besar dari nilai kapasitas angkut, seperti sub DAS 1 dengan nilai $11833130.27>$ 25924.71115 (SE>Tc) dan sub DAS 2 dengan nilai $61212.60687<800875.7768$ (SE<Tc) tidak terjadi sedimentasi karena nilai erosi menunjukkan lebih kecil dari nilai kapasitas angkut yang terjadi pada DAS tersebut.
\end{abstract}

Kata Kunci: Tata guna lahan, Sedimentasi lahan, erosi, USLE, SIG

\begin{abstract}
Modifying of Sail watershed land-use will increase the surface flow and causes erosion and sedimentation. USLE is used for estimating the soil erosion and GIS is used for predicting the size of USLE parameters. The results of the analysis show that erosion occurred at DAS Sail is a category of low class (15-60 ton/ha/year). The results of the research show that on some sub DAS Sail there is land sediment because the erosion value is greater than the value of the carrying capacity, such as sub DAS 1 with the value $11833130.27>25924.71115$ (SE > Tc) and Sub DAS 2 with a value of $61212.60687<800875.7768$ $(S E<T c)$ does not occur because the erosion value shows less than the value of carrying capacity occurring in the watershed.
\end{abstract}

Keywords: Land use, sedimentation,land erosion, USLE, GIS

\section{PENDAHULUAN}

Pekanbaru adalah ibu kota Provinsi Riau yang memiliki luas $\pm 632.26 \mathrm{~km}^{2}$. Kota Pekanbaru dibelah oleh Sungai Siak dan Daerah Aliran Sungai (DAS) Sail yang merupakan sub DAS dari Daerah Aliran Sungai (DAS) Siak. DAS Sail melewati beberapa kecamatan yang ada di Pekanbaru yaitu Kecamatan Sail, Kecamatan Lima Puluh, Kecamatan Bukit Raya, dan Kecamatan Tenayan Raya [4].

Dengan meningkatnya pertumbuhan penduduk Pekanbaru, serta meningkat pula kebutuhan masyarakatnya, dengan ini semakin bertambah kebutuhan lahan baik untuk bercocok tanam maupun untuk lahan pemukiman. Perubahan tata guna lahan pada DAS Sail tidak terkendali lagi dan menurunnya daya dukung lingkungan, tentu menyebabkan berkurangnya lahan untuk menyerap air dan dapat meningkatnya limpasan permukaan pada sungai Sail
[4]. Karena berkurang nya daya serap air, maka erosi tanah juga semakin besar dan terjadi pendangkalan pada sungai dan sering terjadi banjir di sekitar DAS Sail.

Erosi menentukan berhasil atau tidaknya suatu pengelolaan lahan, oleh karena itu erosi merupakan faktor yang harus dipertimbangkan dalam perencanaan penggunaan lahan dan pengelolaannya. Salah satunya dengan menggunakan model prediksi erosi yang harus memenuhi syarat-syarat seperti mudah digunakan dengan data yang minimum, dan memiliki kemampuan untuk mengikuti perubahanperubahan tata guna lahan [2].

Banyak model erosi yang telah dikembangkan saat ini, salah satunya adalah USLE (Universal Soil Loss Equation). Model ini dirancang untuk memprediksi rata-rata erosi tanah dalam waktu yang panjang dari suatu lahan tertentu. Dari permasalahan di atas dilakukan pengkajian tentang erosi dan sedimentasi pada sungai Sail untuk mengetahui 
besarnya erosi dan sedimentasi yang masuk ke sungai Sail dengan menggunakan metode USLE. Selain metode yang sederhana, metode USLE sangat baik digunakan pada daerah yang memiliki penyebab erosinyahujan serta aliran permukaan [7].

Permodelan yang berkembang saat ini adalah permodelan yang diintegrasikan ke dalam Sistem Informasi Geografis (SIG). SIG adalah suatu sistem (berbasis komputer) yang digunakan untuk menyimpan dan memproses informasi-informasi spesial [9]. Pemanfaatan SIG sebagai alat permodelan dalam memprediksi erosi bisa membantu keakuratan data yang dihasilkan pada lahan yang memiliki topografi yang kompleks. Selain untuk memanajemen data yang bereferensi geografi dengan cepat SIG juga akan sangat mempermudah dalam pembuatan model untuk laju erosi untuk penentuan tingkat bahaya erosi terutama pada daerah penelitian, dalam hal ini adalah DAS Sail.

Berdasarkan penelitian sebelumnya yang dilakukan oleh Muhammad Hadi Hasibuan (2015) dengan judul "Analisis Erosi dan Sedimentasi Lahan DAS Uwai Kabupaten Kampar dengan Menggunakan Metode USLE berbasis Sistem Informasi Geografis (SIG)" persamaan penelitian ini sama-sama membahas tentang analisis erosi dan sedimentasi dengan metode USLE yang berbasis SIG. sedangkan untuk perbedaan nya pada lokasi penelitian yaitu pada DAS Uwai kabupaten Kampar[6].

Penelitian selanjutnya yang relevan adalah penelitian yang dilakukan oleh Lukman Nul Hakim (2018) dengan judul "Analisis Potensi Erosi DAS Petapahan Pada Embung Petapahan". Penelitian yang dilakukan oleh Lukman Nul Hakim ini merupakan penelitian analisis potensi erosi menggunakan metode USLE dan berbasis SIG, serta melakukan simulasi rekondisi penutupan lahan akibat volume erosi yang besar masuk ke embung. Penelitian ini dilakukan pada DAS Petapahan, embung Petapahan[5].

Penelitian oleh Hafiz Catur Anggoro (2018) yang berjudul "Analisis Potensi Erosi Sub DAS Galugua Kecamatan Kapur IX Menggunakan Pendekatan Universal Soil Loss Equation (USLE)" ersamaan penelitian ini sama-sama membahas analisis potensi erosi dengan pendekatan USLE, sedangkan perbedaan dari penelitian ini adalah lokasi penelitian yang dilakukan pada DAS Galugua Kecamatan Kapur IX[1].

\section{METODE PENELITIAN}

\section{Lokasi Penelitian}

Daerah Aliran Sungai (DAS) Sail termasuk dalam sub DAS Siak yang berada di Pekanbaru yang melewati empat kecamatan seperti kecamatan Sail, Tenayang Raya, Lima Puluh dan Bukit Raya. Dengan panjang sungai tersebut $\pm 29 \mathrm{~km}$ dan memliki luas daerah tangkapan air (Catchment area) sebesar $\pm 29 \mathrm{~km}^{2}$ [7].

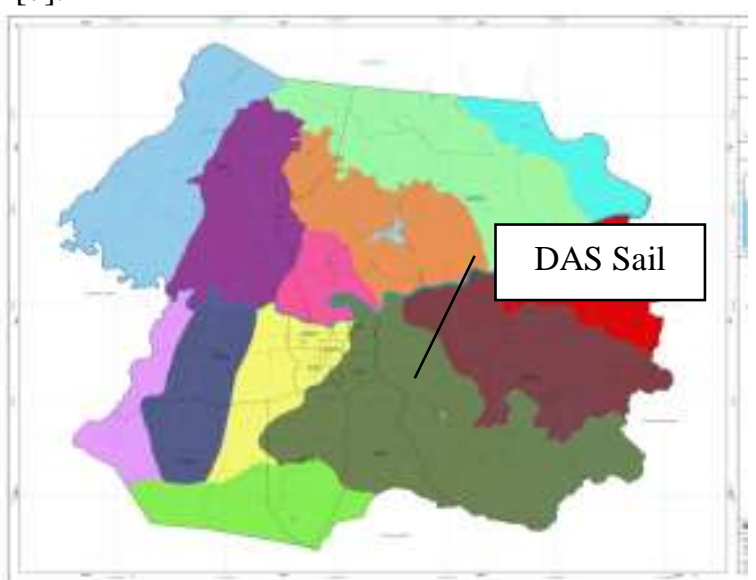

Gambar 1 Peta Kota Pekanbaru

(sumber : PUPR Kota Pekanbaru, 2013)

\section{Diagram Alir Penelitian}

Pada penelitian ini terdapat beberapa tahapan, untuk lebih jelasnya dapat dilihat pada Gambar 2.

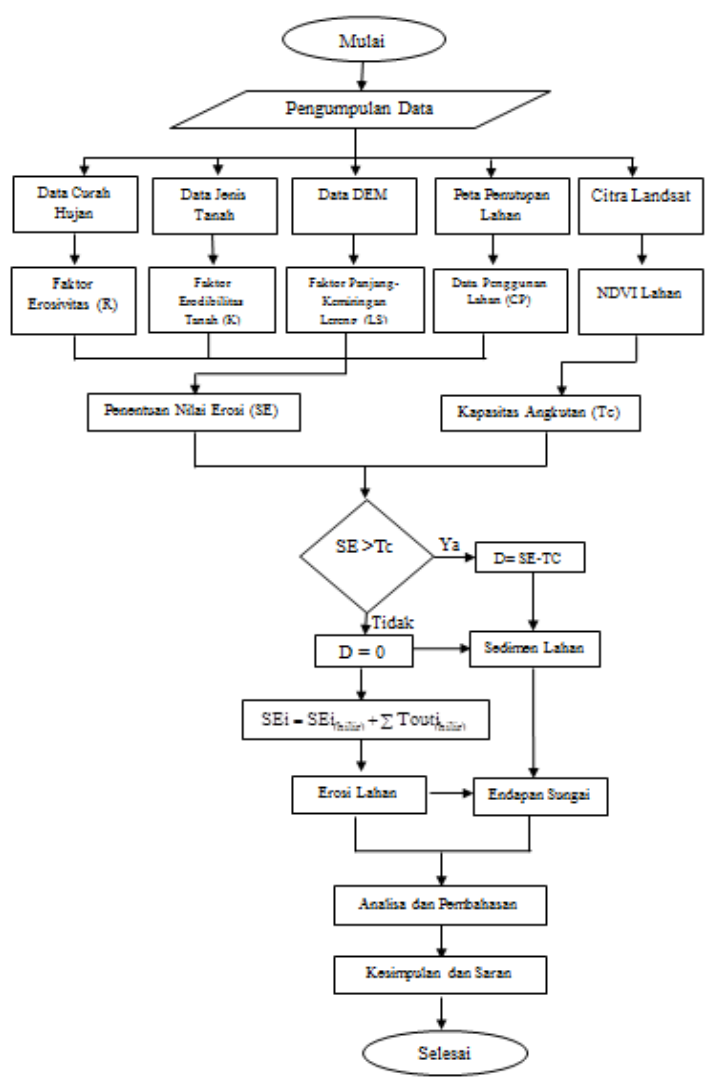

Gambar 2 Diagram Alir 
Diagram alir pada Gambar 2 menggambarkan proses perencanaan mulai dari mengumpulkan berbagai data yang diperlukan seperti Data curah hujan dalam kala 10 tahun, Data jenis tanah, Data DEM, Peta penutupan lahan dan Citra Landsat yang diperoleh dari berbagai Sumber. Dari data-data tersebut diperoleh parameter-parameter yang digunakan dalam analisa perhitungan Nilai Erosi, Parameter tersebut didapatkan baik secara manual dan analisis menggunakan Sistem Informasi Geografis (SIG). Analisis pada SIG ini dilakukan untuk mendapatkan Peta Faktor Panjang dan kemiringan lereng berdasarkan data DEM.

Kapasitas angkutan (Tc) yang diperoleh berdasarkan nilai dari NDVI yang berdasarkan pada jenis sebaran vegetasi pada masing-masing lahan. Setelah nilai NDVI ditentukan dengan menggunakan SIG dan peta citra landsat 8 , Selanjutnya adalah penentuan endapan lahan dengan ketentuan sebagai berikut :

a. Jika terjadi erosi tanah yang lebih besar dari kapasitas angkutan maka terjadi endapan (SE > Tc), dengan $\mathrm{D}=\mathrm{SE}-\mathrm{Tc}$. Jadi angkuan sedimen keluar melalui hilir $\left(\mathrm{T}_{\text {out }}\right)$ sama dengan kapasitas angkutan $\left(\mathrm{T}_{\text {out }}=\mathrm{Tc}\right)$ untuk penentuan erosi totalnya Total $\mathrm{SE}_{\text {hilir }}=\mathrm{SEi}_{\text {(hilir) }}+\Sigma$ Touti $_{\text {(hulu) }}$

b. Jika erosi tanah yang lebih kecil dari kapasitas angkutan maka pada DAS tersebut tidak terjadi endapan $(\mathrm{SE}<\mathrm{Tc})$, dengan $\mathrm{D}=0$ Angkutan sedimen keluar $\left(\mathrm{T}_{\text {out }}\right)$ melalui hilir sama dengan besaran erosi tanah tersebut $\left(\mathrm{T}_{\text {out }}=\mathrm{SE}\right)$ untuk penentuan erosi tanah total dapat direncanakan sebagai berikut TotalSEhilir $=$ SEi $($ hilir $)+\sum$ Touti $($ hulu $)$

Gambar 2 adalah diagram alir penelitian tentang Kajian Sedimentasi pasa DAS Sail Pekanbaru dengan Menggunakan SIG dan Metode USLE.

\section{Penentuan Erosi dengan Metode USLE}

Penelitian ini menggunakan model pendugaan erosi menggunakan metode Universal Soil Loss Equation (USLE). Metode Untuk memprediksi nilai erosi dengan menggunakan metode USLE yang diperoleh dari hubungan antara beberapa faktor penyebab dari erosi tersebut yaitu dengan:

$$
\mathrm{E}=\text { R.K.LS.C.P }
$$

Dengan E : Besarnya Kehilangan tanah persatuan luas lahan (ton/ha/tahun), R : Erosivitas curah hujan tahunan rata-rata (rainfall-runoff erosivity), $\mathrm{K}$ : Indeks erodibilitas tanah (Soil Erodibility), LS : Indeks Panjang dan kemiringan lereng, $\mathrm{C}$ : Indeks penutupan lahan (Cropping management), P : Indeks upaya konservasi tanah/lahan ,

Peta erosivitas DAS Sail diperoleh dari data curah hujan selama 10 tahun $(2008$ - 2017) . Data curah hujan ini diperoleh dari BWS III Provinsi Riau. Nilai total tiap bulan nya dapat dihitung dengan menggunakan persamaan Lenvain [3] sebagai berikut :

$$
\begin{aligned}
R m & =2,2(\text { Rain }) m^{1,36} \\
R & =\sum_{m=1}^{12} R m
\end{aligned}
$$

Peta Erodibilatas tanah dibuat dengan bantuan peta jenis tanah, agar mendapatkan peta erodibilitas maka dilakukan dengan cara tumpang tindih (Overlay) antara peta DAS Sail dengan Peta jenis tanah Kota pekanbaru yang diperoleh dari dinas PUPR Kota Pekanbaru. Peta Kemiringan lereng dengan peta tutupan lahan juga diperoleh dengan melakukan Overlay antara peta DAS Sail dengan masing-masing Peta Kemiringan lereng dan peta tutupan lahan kota Pekanbaru

\section{Peta Sebaran Erosi}

Peta sebaran erosi diperoleh dari hasil tumpang tindih (overlay) antara faktor-faktor yang mempengaruhi USLE. Adapun beberapa faktor tersebut adalah faktor erosivitas (R), faktor erodibilitas (K), faktor kemiringan lereng (LS) dan faktor tutupan lahan (CP). Faktor tersebut di overlay dengan bantuan aplikasi Sistem Informasi Geografis (SIG). Hasil dari overlay tersebut adalah jumlah erosi yang terjadi pada setiap sub DAS Sail. Besaran erosi terdapat beberapa kelas berdasarkan besaran erosi yang terjadidalam satu hektar petahunnya. Tabel 1 Klasifikasi Kelas Erosi

\begin{tabular}{ccc}
\hline Kelas & $\begin{array}{c}\text { Besaran Erosi } \\
\text { (ton/ha/tahun) }\end{array}$ & Keterangan \\
\hline 1 & $<15$ & Sangat Rendah \\
2 & $15-60$ & Rendah \\
3 & $60-180$ & Sedang \\
4 & $180-480$ & Berat \\
5 & $>480$ & Sangat Berat \\
\hline
\end{tabular}

Sumber : Abdul Rauf (2011)

\section{Penentuan Kapasitas Angkutan Sedimen}

Untuk menentukan besar endapan lahan dan penyaluran sedimentasi, yang pertama kali dilakukan adalah membuat alur angkutan dari suatu sub DAS menuju sub DAS berikutnya. Selanjutnya penentuan besar kapasitas angkut sediemen pada masing-masing sub DAS. Kapasitas angkut sedimen yaitu kemampuan suatu aliran yang membawa erosi tanah dari satu lahan ke lahan yang lainnya. Kapasitas angkutan sedimen dapat dihitung dengan menggunakan persamaan Verstraten (Jain, $K, M$, 2010) berikut :

$$
T C i=K_{T C i} R K_{i} A_{s i}^{1,44} S_{i}^{1,44}
$$


Dengan : $\mathrm{K}_{\mathrm{TCi}}$ dihitung berdasarkan nilai Normalized Deifference vegetation index (NDVI) seperti persamaan berikut :

$$
K_{T C i}=\beta^{*} \exp \left[\frac{-N D V I}{1-N D V I}\right]
$$

DAS Sail dengan Luas 12140,316 Ha terdiri dari 7 sub DAS, dan diberi penomoran 1 sampai 7 (Gambar 2). Tujuh Sub DAS yang ada pada DAS Sail di Overlay terhadap peta sebaran erosi tanah pada sub DAS Sail yang telah dibuat dengan metode USLE.

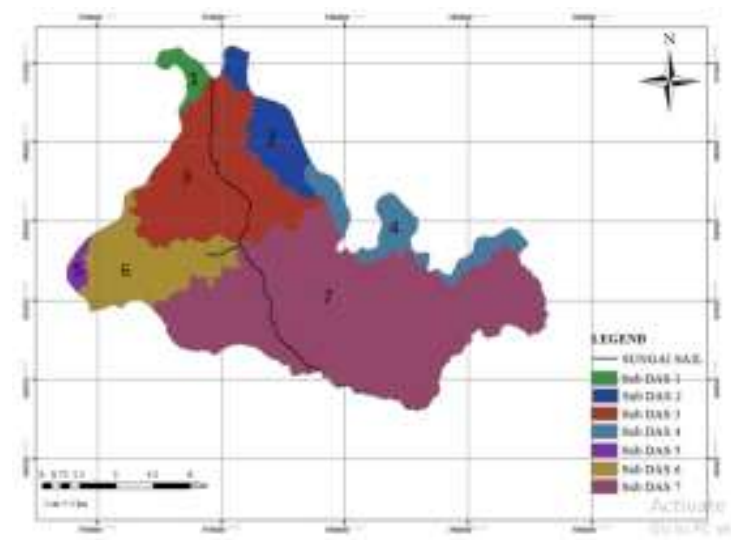

Gambar 3 Penomoran Sub DAS Sail

Berikutnya menentukan besar kapasitas angkut yang terjadi pada setiap sub DAS yang berdasarkan dengan jenis vegetasi pada masing-masing sub DAS tersebut.

\section{Sedimentasi Lahan}

Besarnya endapan pada lahan dapat ditentukan berdasarkan beberapa ketentuan sebagai berikut:

a. Jika besaran erosi tanah (SE) yang terjadi lebih besar dibandingkan dengan kapasitas angkutan sedimen (TCi) pada sub DAS hulu, maka akan terjadi sedimentasi atau endapan (D) pada sub DAS sebesar :

$\mathrm{Di}=\mathrm{SEi}-\mathrm{Tci}$

Jadi erosi yang tertinggal sama dengan endapan yang terjadi pada sub DAS tersebut (SE=D). Angkutan sedimen keluar (Tout ${ }_{\mathrm{i}}$ ) yang keluar berdasarkan alur ke sub DAS hilir yang terdekat sesuai dengan alur angkutan tersebut sebesar :

Touti $=\mathrm{TCi}$

Angkutan sedimen yang keluar dari sub DAS hulu akan bergabung menjadi besaran erosi tanah pada sub DAS hilir yang terkoneksi berdasarkan alur, maka nilai total erosi tanah pada sub DAS hilir sebagai berikut :

Total $\mathrm{SE}_{\text {hilir }}=\mathrm{SEi}_{\text {(hilir) }}+\Sigma$ Touti $_{\text {(hulu })}$

b. Jika besaran erosi tanah (SE) lebih kecil dibandingkan dengan kapasitas angkut sedimentasi (TCi) pada sub DAS hulu, maka tidak terjadi endapan atau sedimentasi (D) atau erosi akan keluar semua dari sub DAS tersebut, jadi:

$\mathrm{Di}=0$

Angkutan sedimen keluar (Tout ${ }_{\mathrm{i}}$ ) yang keluar melalui alur ke sub DAS hilir sesuai dengan alur angkutan sebesar :

Tout $_{\mathrm{i}}=\mathrm{SE}_{\mathrm{i}}$

Angkutan sedimen yang keluar dari sub DAS hulu akan bergabung menjadi besaran erosi tanah pada sub DAS hilir yang telah terhubung dengan alur yang telah direncanakan, maka total erosi tanah pada sub DAS hilir tersebut adalah:

Total $\mathrm{SE}_{\text {hilir }}=\mathrm{SE}_{\text {(hilir) }}+\Sigma$ Tout $_{\text {(hulu) }}$

\section{HASIL DAN PEMBAHASAN}

\section{Faktor Erosi}

Hasil dari analisis data curah hujan kota Pekanbaru selama 10 tahun dari tahun 2008 sampai dengan tahun 2018. Data curah hujan tersebut disubstitusikan dengan persamaan 2 supaya mendapatkan nilai erosivitas (R). berikut adalah contoh perhitungannya pada bulan januari.

Total hujan bulan Januari dari tahun 2008 sampai dengan 2017 dijumlahkan yang hasilnya : $1244,3 \mathrm{~mm}: 124,4 \mathrm{~cm}$.

(Rain)m : 124,4/10

: $12,44 \mathrm{~cm}$

Berdasarkan perhitungan dari persamaan 2

$\begin{array}{ll}\mathrm{R} & : 2,21 \text { (Rain) }^{1,36} \\ \mathrm{R} & : 2,21 \times(12,44)^{1,36} \\ \mathrm{R} & : 68,15 \mathrm{~cm}\end{array}$

$\mathrm{R} \quad: 68,15 \mathrm{~cm}$ 
Tabel 2 Erosivitas Hujan DAS Sail

\begin{tabular}{lcccccccccccc}
\hline & Jan & Feb & Mar & Apr & Mei & Jun & Jul & Agust & Sep & Okt & Nov & Des \\
\hline Rata2/Tahun & 12.4 & 13.4 & 18.7 & 23.0 & 12.6 & 10.6 & 13.9 & 10.9 & 14.3 & 21.0 & 21.5 & 14.7 \\
Erosivitas (R) & 68.1 & 75.6 & 118.3 & 157.1 & 69.4 & 54.8 & 79.2 & 57.0 & 82.6 & 139.2 & 143.2 & 85.2 \\
\hline $\begin{array}{l}\text { R Total } \\
(\mathrm{cm} / \text { tahun })\end{array}$ & & & & & & 1129.69 & & & & & \\
\hline
\end{tabular}

Pada Tabel 2 terlihat hasil Erosivitas hujan pada wilayah DAS Sail sebesar $1129.69 \mathrm{~cm} / \mathrm{tahun}$.

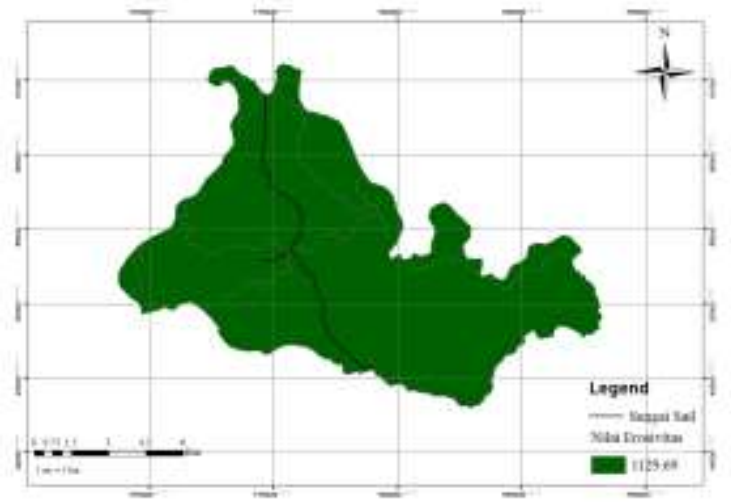

Gambar 4 Peta Nilai Erosivitas hujan DAS Sail

Gambar 4 terlihat seluruh DAS Sail tersebar dengan luas 12140,316 Ha dan peta sebaran nilai erosivitas (R) sebesar 1129,69 cm/tahun (Gambar 5).

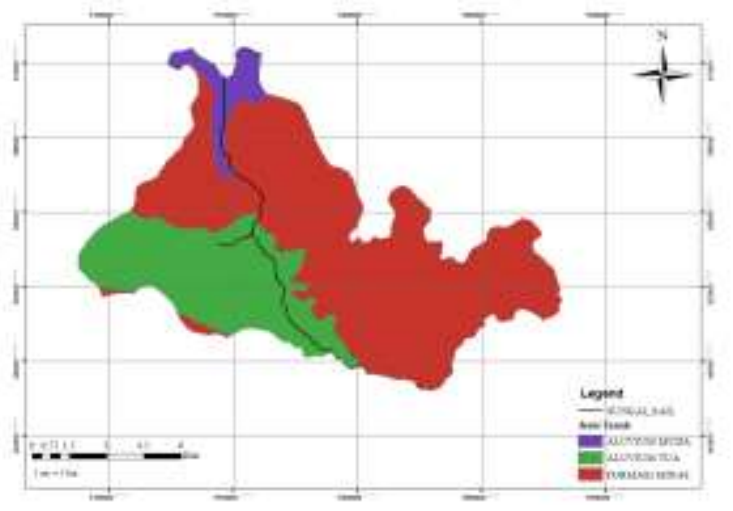

Gambar 5 Peta Jenis Tanah DAS Sail

Dengan menggunakan bantuan sistem informasi geografis (SIG) peta jenis tanah DAS Sail (Gambar 5) dan peta tata guna lahan (Gambar 6) diidentifikasi berdasarkan pengelolaan dan penggunaan lahan, peta jenis tanah pada masing-masing daerah.

Pada Gambar 4 nilai jenis tanah yang terdapat pada DAS Sail terdapat tiga jenis yaitu Aluvium Muda dengan nilai erodibilitas (K) 0,251, Aluvium Tua nilai erodibilitas $(\mathrm{K})$ nya 0,073 dan Formasi Minas dengan nilai erodibilitas nya $(K) 0,24$. Nilai erodibilitas tanah diambil dari Rauf A, 2010 dan Arsyad,1989.

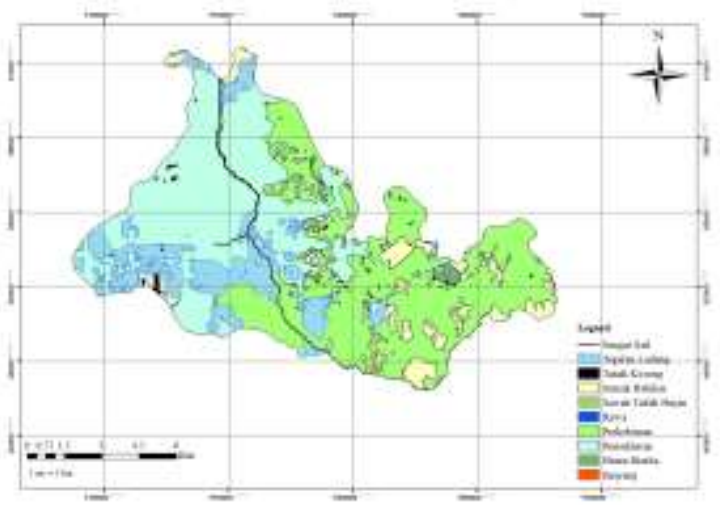

Gambar 6 Peta Tutupan Lahan

Pada Gambar 6 terdapat 9 jenis tutupan lahan yang terdapat pada DAS Sail. Tutupan lahan yang lebih dominan pada DAS Sail adalah perkebunan yang dilambangkan dengan warna hijau dan pemukina dengan warna biru. Untuk luasan dan nilai tutupan lahan dapat dilihat pada Tabel 3

Tabel 3 Luas dan nilai faktor tutupan lahan DAS Sail

\begin{tabular}{ccc}
\hline Penutupan Lahan & $\begin{array}{c}\text { Luas } \\
(\mathrm{Ha})\end{array}$ & Nilai CP \\
\hline Tegalan Ladang & 1576.63 & 0.19 \\
Tanah Kosong & 88.13 & 0.95 \\
Semak Belukar & 800.12 & 0.3 \\
Sawah Tadah Hujan & 41.37 & 0.01 \\
Rawa & 2.33 & 0.01 \\
Perkebunan & 4788.47 & 0.5 \\
Permukiman & 4729.21 & 0.5 \\
Hutan Rimba & 58.29 & 0.01 \\
Empang & 6.68 & 0.001 \\
\hline Total & 12091.24 & \\
\hline
\end{tabular}

Pada Tabel 3 diperoleh total luas daerah tutupan lahan 12091,24 Ha. Perkebunan merupakan tutupan lahan pada DAS Sail yang lebih dominan dengan luas 4788,47 Ha, dan nilai CP 0.5. Rawa adalah tutupan lahan pada DAS Sail yang luasnya kecil, yaitu 2,33 Ha, dengan nilai CP 0,01. Nilai CP 
yang diperoleh berdasarkan Tabel 2.3 nilai CP untuk berbagai faktor penggunaan lahan.

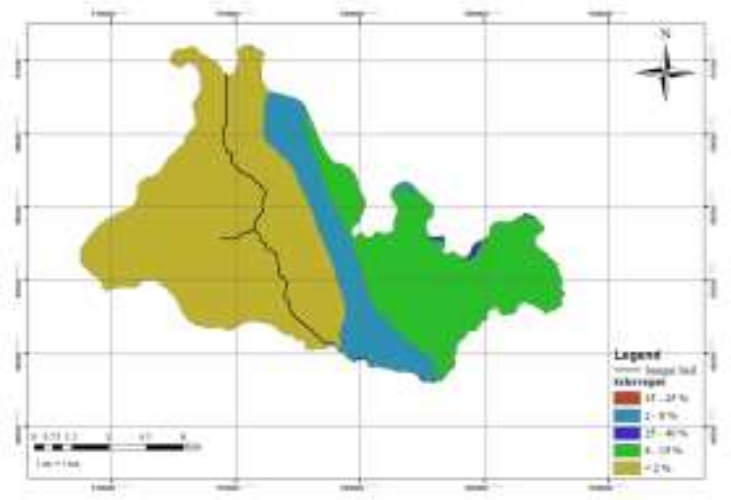

Gambar 7 Peta Kemiringan Lereng DAS Sail

Dengan bantuan perangkat SIG diperoleh nilai faktor kemiringan lereng DAS Sail (Gambar 7). Selanjutnya seluruh peta faktor yang mempengaruhi USLE ditumpang tindihkan (Overlay) satu sama lainnya yang akan memberikan informasi baru yaitu peta sebaran erosi.

\section{Sebaran Kelas Erosi}

Peta sebaran kelas erosi memberikan informasi tentang lokasi kelas erosi DAS Sail (Gambar 8)

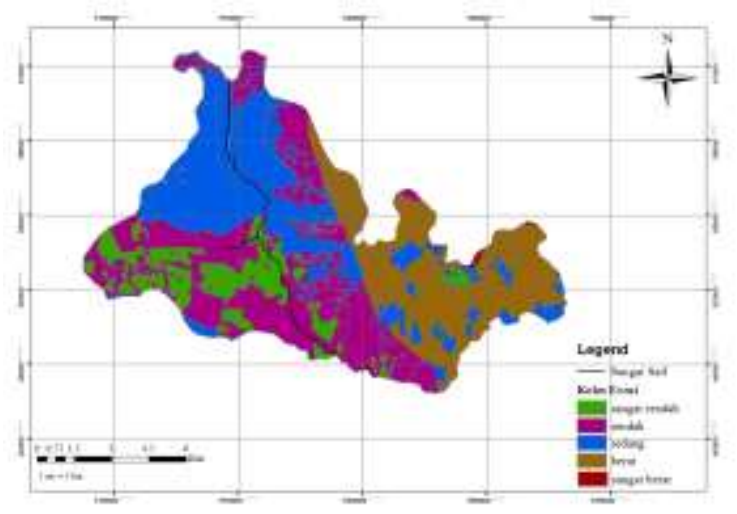

Gambar 8 Peta Sebaran Erosi

Berdasarkan dari Gambar 7 Peta sebaran erosi, maka hasil yang didapat dari proses overlay dengan menggunakan SIG, dan menghitung jumlah erosi berdasarkan persamaan metode USLE didapatkan 5 kelas erosi pada DAS Sail. Adapun kelas erosi pada DAS Sail yaitu Sangat rendah (Kelas 1) dengan laju erosi <15 Ton/Ha/Tahun memiliki luas 1410.558Ha. Rendah (Kelas II) dengan laju erosi dari 15-60 Ton/Ha/Tahun dan luas $3899.081 \mathrm{Ha}$. Sedang (Kelas III) memiliki kejadian laju erosi 60$180 \mathrm{Ton} / \mathrm{Ha} / \mathrm{Tahun}$ dengan luas $3696.641 \mathrm{Ha}$. Berat (Kelas IV) dengan laju erosi 180-480 Ton/Ha/Tahun memiliki luas 2980.273 Ha. Sangat berat (Kelas V) memiliki kejadian laju erosi sebesar >480 $\mathrm{Ton} / \mathrm{Ha} / \mathrm{Tahun}$ dengan luas $31.832 \mathrm{Ton} / \mathrm{Ha} / \mathrm{Tahun}$.

\section{Endapan Lahan dan Sedimentasi yang masuk ke sungai}

Hasil erosi yang terjadi pada DAS Sail sebagian akan mengendap pada sebagian lahan dan sebagian lagi akan terangkut menjadi sedimen dan masuk ke dalam sungai. Angkutan yang mengalami pengendapan pada sungai akan menyebabkan pendangkalan pada sungai tersebut dan berdampak mengalami penurunan kapasitas tampungan sungai.

Dalam menentukan kapasitas angkutan diperlukan nilai NDVI (Normalized Difference Vegetation Index). Nilai NDVI digunakan untuk mencari koefisien kapasitas angkutan sedimen (KTc). Peta NDVI (Gambar 9) akan ditumpang tindihkan (overlay) dengan peta pembagian sub DAS, hasil dari overlay tersebut akan menghasilkan nilai NDVI rata-rata tiap sub DAS.

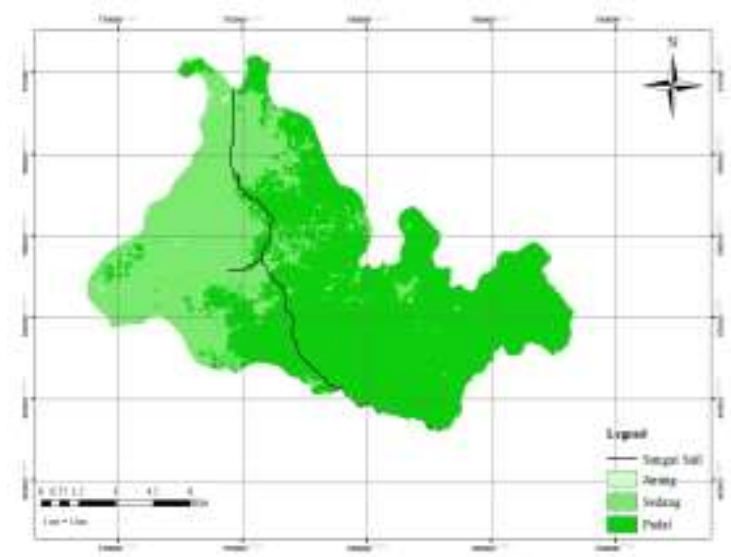

Gambar 9 Peta Nilai NDVI DAS Sail

Berdasarkan analisis dari data SIG diperoleh hasil klasifikasi tingkat kerapatan vegetasi pada DAS Sail, terbagi menjadi 3 kelas yaitu Jarang, sedang, dan padat. Selanjutnya dilakukan overlay pada nilai NDVI yang telah didapat dengan Peta sebaran erosi DAS Sail, agar diketahui nilai NDVI di setiap sub DAS tersebut. Nilai sebaran Vegetasi (NDVI) pada DAS Sail memiliki nilai terkecil 0.1 dan terbesar dengan nilai 0.3. Dari nilai NDVI didapat koefisien kapasitas angkut sedimen (KTc) berdasarkan persamaan 5. Berikut tabel nilai koefisien kapasitas angkutan sedimen pada masingmasing sub DAS.

Tabel 4 Hasil Perhitungan Kapasitas Angkutan masing-masing sub DAS

\begin{tabular}{ccc}
\hline Sub DAS & KTc & A (Ha) \\
\hline 1 & 0,760135461 & 208,593417 \\
2 & 0,704295772 & 763,772382 \\
3 & 0,747909553 & 2619,298685 \\
4 & 0,65972088 & 796,291196 \\
5 & 0,777639035 & 110,854133 \\
6 & 0,768295301 & 1396,461493 \\
7 & 0,66534227 & 6245,044798 \\
\hline
\end{tabular}


Nilai kapasitas angkut lahan (Tc) yang diperoleh dari nilai koefisien kapasitas angkut (KTc) pada masing-masing sub DAS tersebut dengan menggunakan persamaan 4. Setelah nilai kapasitas angkut tiap sub DAS didapat, maka dibandingkan dengan nilai erosi yang terjadi pada tiap sub DAS. Berikut adalah rekapitulasi hasil erosi, kapasitas angkut sedimen serta endapan lahan dan penyaluran sedimen yang ada pada DAS Sail.

Tabel 5 Hasil perhitungan endapan lahan dan penyaluran sedimen

\begin{tabular}{ccccccccc}
\hline $\begin{array}{c}\text { Sub } \\
\text { DAS }\end{array}$ & $\begin{array}{c}\text { Arah } \\
\text { Tout }\end{array}$ & $\begin{array}{c}\text { Tin } \\
\text { dari }\end{array}$ & $\begin{array}{c}\text { Tin } \\
\text { (ton/tahun) }\end{array}$ & $\begin{array}{c}\text { Erosi } \\
\text { (ton/tahun) }\end{array}$ & $\begin{array}{c}\text { Erosi+ Tin } \\
\text { (ton/tahun) }\end{array}$ & $\begin{array}{c}\text { Tc } \\
\text { (ton/tahun) }\end{array}$ & $\begin{array}{c}\text { Tout } \\
\text { (ton/tahun) }\end{array}$ \\
\hline 7 & 3 & 4 & 4259941,037 & 622757,6299 & 4882698,667 & 206752467,1 & 4882698,667 \\
(ton/tahun)
\end{tabular}

Pada Tabel 5 Nilai sedimentasi lahan yang didapat dari pengurangan antara nilai erosi yang terjadi dengan nilai kapasitas angkutan yang terjadi pada setiap sub DAS tersebut. Sub DAS Sail nilai kapasitas angkutan sangat besar dibandingkan dengan nilai erosi yang terjadi, maka hasil erosi yang ada pada lahan akan terbawa masuk ke dalam sungai, ini terjadi karena sebaran vegetasi yang ada di sub DAS Sail tidak terlalu baik dan membuat kemampuan lahan untuk menahan erosi yang terjadi pada lahan tidak ada. Hal ini terjadi pada semua sub DAS terkecuali pada sub DAS 3 dan sub DAS 5.

Pada DAS 3 dan DAS 5 hasil erosi yang terjadi tidak langsung terbawa ke sungai, hasil sediemntasi mengendap pada lahan. Tata guna lahan pada DAS Sail ini bagus sehingga memiliki nilai erosi yang kecil dibandingkan dengan nilai kapasitas angkutan yang besar. Berdasarkan hasil perhitungan endapan lahan dan penyaluran sedimen diketahui bahwa hasil erosi yang masuk ke singai adalah 25924,71115 Ton/Tahun.

\section{KESIMPULAN}

Kesimpulan dari penelitian ini adalah :

a. Pada DAS Sail erosi yang terjadi terdapat 5 klasifikasi kelas erosi yaitu kelas 1 (sangat rendah) dengan luas $1410,558 \mathrm{Ha}$, kelas 2 (Rendah) dengan luas 3899,081Ha, kelas 3 (Sedang) 3698,641 Ha, kelas 4 (Berat) 2980,273Ha, kelas 5 (sangat berat) 31,832 Ha. DAS Sail termasuk dalam kategori kelas 2 yaitu rendah, karena memiliki luasan yang paling besar. b. Erosi yang masuk ke dalam sungai yang berasal dari sub DAS 1 memiliki Volume sebesar 25924,71115 Ton/Tahun.

c. Sedimentasi yang terjadi pada sub DAS 5 sebesar 201913,0333 ton/tahun, pada sub DAS 3 sedimentasi yang terjadi sebesar 196902876,2 ton/tahun dan pada sub DAS 1 terjadi sedimentasi sebesar 11807205,56 ton/tahun.

d. Pada sebagian sub DAS tidak terjadi sedimentasi $(\mathrm{D}=0)$ karena nilai erosinya lebih kecil dibandingkan nilai kapasitas angkutan ( $\mathrm{SE}<\mathrm{Tc})$, sub DAS $2(61212,60687<800875,7768)$, sub DAS $4(182293<4259941,037)$, sub DAS 6 $(38278,78117<918030,9167)$, sub DAS 7 $(4882698,667<206752467,1)$.

Adapun saran dari penelitian ini adalah :

Penelitian ini menggunakan metode USLE untuk menghitung erosi pada lahan sehingga untuk penelitian yang sama selanjutnya dapat membandingkan dengan menggunakan metodemetode lain. Sebaiknya dalam pembagian sub DAS lebih sedikit, karena lebih mempermudah dalam perhitungan sebaran erosi dan NDVI.

\section{DAFTAR PUSTAKA}

[1] Anggoro, H.C. (2018). Analisis Potensi Erosi sub DAS Galugua Kecamatan Kapur IX menggunakan Pendekatan Universal Soil Loss Equarion (USLE). Skripsi Sarjana, Jurusan Teknik Sipil, Universitas Riau.

[2] Arsyad, S. (2000). Konversi Tanah dan Air. Bogor: IPB Press. 
[3] Bambang. S. 2011. Pengaruh Erosivitas Hujan Yang Diperoleh Dari Rumus Yang Berbeda Terhadap Pemodelan Erosi Berbasis Raster. Bengkulu : Universitas Bengkulu.

[4] Desriani, S., \& Adrianty, Y. (2003). Pengaruh Debit Limpasan Terhadap Debit Banjir pada Daerah Aliran Sungai (DAS) Sail Kota Pekanbaru. Pekanbaru.

[5] Hakim, L.N. (2018). Analisis Potensi Erosi DAS Petapahan dan Sedimentasi Embung Petapahan. Skripsi Sarjana, Jurusan Teknik Sipil, Universitas Riau, Pekanbaru.

[6] Hasibuan, M. H. (2015). Analisis Erosi Lahan Dan Sedimentasi Lahan DAS Uwai Kabupaten Kampar Menggunakan Metode USLE Berbasis Sistem Informasi Geografis (SIG). Pekanbaru: Universitas Riau.

[7] Mulyanto. (2008). Efek Konservasi dari Sistem SABO untuk pengendalian sedimentasi waduk. yogyakarta: Graha Ilmu.

[8] Vadari, e. a. (2006). Model Prediksi Erosi : Prinsip, Keunggulan, dan Keterbatasan. Bogor: IPB.

[9] Prahasta, E. (2009). Sistem Informasi Geografis Konsep-konsep Dasar. Bandung: Informatika Bandung.

[10] Putra, R. P., Elvyra, R., \& Khairijon. (2012). Kualitas Perairan Sungai Sail Kota Pekanbaru Berdasarkan Koefisien Saprobik. Pekanbaru: Fakultas Matematika dan Ilmu Alam Universitas Riau. 